\title{
W kwestii wyższego stopnia naukowego doktora w Polsce Ludowej
}

\section{Wprowadzenie}

Wzorem rozwiązań Polski międzywojennej w Polsce Ludowej sprawy stopni naukowych normowano prawem szkolnictwa wyższego. Pierwszy akt prawny ówcześnie reformujący szkolnictwo wyższe wdrożono dopiero po ponad dwuletnim okresie od zakończenia II wojny światowej. W 1945 r. nie oznaczało to wszakże braku podstaw prawnych określających warunki i zasady prowadzenia szkół wyższych, kształcenia studentów i nadawania stopni naukowych. Nadal obowiązywały ustawy: z 1933 r. o szkołach akademickich ${ }^{1}$, z 1932 r. o ustroju szkolnictwa ${ }^{2}$ i z 1937 r. o prywatnych szkołach wyższych ${ }^{3}$. Prawo nadawania stopni naukowych, wtedy zarezerwowane wyłącznie dla szkół akademickich, pozostawiono w kształcie unormowanym ustawą z 1933 r., która przewidywała dwa stopnie naukowe: niższy i wyższy ${ }^{4}$. W szkołach akademickich wyższym stopniem naukowym był stopień doktora.

Pierwszą powojenną reformę szkolnictwa wyższego wprowadzono Dekretem z dnia 28 października 1947 r. o organizacji nauki i szkolnictwa wyższego ${ }^{5}$. Wdrożone nim zmiany w zakresie ustroju i funkcjonowania szkolnictwa wyższego oraz naboru na studia i kształcenia

${ }^{1}$ Ustawa z dnia 15 III 1933 r. o szkołach akademickich (tekst jedn. Dz.U. RP 1938 Nr 1, poz. 6 ze zm.).

${ }^{2}$ Ustawa z dnia 11 III 1932 r. o ustroju szkolnictwa (Dz.U. RP Nr 30, poz. 389 ze zm.).

${ }^{3}$ Ustawa z dnia 22 II 1937 r. o prywatnych szkołach wyższych (Dz.U. RP Nr 13, poz. 89).

${ }^{4} \mathrm{Na}$ temat niższych i wyższych stopni naukowych w Polsce międzywojennej zob. K. Wojtczak, O stopniach naukowych i veniam legendi w II Rzeczypospolitej (Część I), „Studia Prawa Publicznego" 2014, nr 3(7), s. 31-66.

${ }^{5}$ Dz.U. Nr 66, poz. 415. 
studentów bez wątpienia odbiegały od rozwiązań Polski międzywojnia 6 . $\mathrm{W}$ odniesieniu do stopni naukowych natomiast zmiany prawne nie były tak znaczące. Dekret zachował dwa stopnie naukowe: niższy - magistra i wyższy - doktora oraz prawo szkół akademickich do ich nadawania. Określenie zasad i trybu nadawania stopni naukowych w drodze rozporządzenia leżało w gestii ministra oświaty ${ }^{7}$.

Rok 1951 przyniósł nowe rozwiązania ${ }^{8}$. Szkoły wyższe (już nie o charakterze akademickim) poddano nowym regułom, silniej je podporządkowującym organom centralnym zarówno w sferze zarządzania szkołą wyższa, jak i programów nauczania. Bardziej rewolucyjne zmiany bez wątpienia dotyczyły stopni naukowych. Ukończenia studiów już nie wiązano z prawem nabycia niższego stopnia naukowego. Ich ukończenie potwierdzone tytułem (od $1956 \mathrm{r}$. stopniem zawodowym) magistra, lekarza lub inżyniera magistra ${ }^{9}$ dawało jedynie prawo ubiegania się o wszczęcie przewodu prowadzącego do uzyskania niższego stopnia naukowego. Odtąd prawodawca przewidywał dwa stopnie naukowe: niższy - kandydata nauk, wyższy - doktora nauk.

Zgodnie z rozwiązaniami przyjętymi w $1958 \mathrm{r}$. kolejną ustawą o szkolnictwie wyższym ${ }^{10}$ stopień naukowy doktora był niższym stopniem naukowym. Tego stanu rzeczy nie zmieniły także postanowienia ustawy z 1965 r. o stopniach naukowych i tytułach naukowych ${ }^{11}$ ani ustawa z roku 1982 o szkolnictwie wyższym ${ }^{12}$.

\footnotetext{
${ }^{6}$ Szerzej na ten temat zob. K. Wojtczak, Prawne determinanty procesu kształcenia w szkołach wyższych w latach 1920-1990 (Część II), „Studia Prawa Publicznego” 2014, nr 1(5), s. 45-87.

${ }^{7} \mathrm{O}$ zmieniających się nazwach i zakresach działania urzędów ministra właściwych do spraw szkolnictwa wyższego zob. K. Wojtczak, Prawne determinanty procesu kształcenia w szkołach wyższych w latach 1920-1990 (Część I), "Studia Prawa Publicznego" 2013, nr 4, s. 68.

${ }^{8}$ Wdrożono je Ustawą z dnia 15 XII 1951 r. o szkolnictwie wyższym i pracownikach nauki (tekst pierwotny Dz.U. $1952 \mathrm{Nr}$ 6, poz. 38). Ustawa ta weszła w życie z moca obowiązującą z dniem 7 II 1952 r.

${ }^{9} \mathrm{~W}$ brzmieniu pierwotnym nadanym art. 24 ust. 2 ustawy z $1951 \mathrm{r}$. chodzi tu o dyplomy ukończenia studiów drugiego stopnia lub równorzędnych, stwierdzające ukończenie tych studiów i uzyskanie tytułu. Od 1956 r. odstąpiono od dwuetapowego kształcenia studentów i nadawania absolwentom tytułów. Odtąd szkoły wyższe wydawały im dyplomy stwierdzające ukończenie studiów i uzyskanie stopnia magistra, lekarza lub inżyniera magistra (art. 1 pkt 22 Ustawy z dnia 10 IX 1956 r. o zmianie ustawy o szkolnictwie wyższym i pracownikach nauki - Dz.U. Nr 41, poz. 185).

${ }^{10}$ Ustawa z dnia 5 XI 1958 r. o szkołach wyższych (Dz.U. Nr 68, poz. 336 ze zm.).

${ }^{11}$ Ustawa z dnia 31 III 1965 r. o stopniach naukowych i tytułach naukowych (Dz.U. Nr 14, poz. 101 ze zm.). Ustawę tę uchylono z dniem 27 IX 1990 r. na mocy Ustawy z dnia 12 IX 1990 r. o tytule naukowym i stopniach naukowych (Dz.U. Nr 65, poz. 386).

${ }^{12}$ Ustawa z dnia 4 V 1982 r. o szkolnictwie wyższym (Dz.U. Nr 14, poz. 113 ze zm.), którą uchylono z dniem 27 IX 1990 r. Ustawą z dnia 12 IX 1990 r. o szkolnictwie wyższym (Dz.U. Nr 65, poz. 385).
} 
Tak więc począwszy od 1919 do 1958 r., czyli przez blisko trzydzieści dziewięć lat, z czego trzynaście przypadało na okres Polski Ludowej, ustawodawca uznawał stopień doktora za wyższy stopień naukowy. Z końcem roku 1958 odstąpił od tego rozwiązania, w wyniku czego przez okres kolejnych trzydziestu dwóch lat (do 1990 r.), już w Polskiej Rzeczypospolitej Ludowej, zapewnił prawo nadawania stopnia doktora wyłącznie jako niższego stopnia naukowego ${ }^{13}$. Oczywiście, to proste przełożenie na lata ówczesnych reform nie uwzględnia w pełni okresów wyznaczonych przepisami przejściowymi każdego z aktów rangi ustawowej zmieniających ówczesne szkolnictwo wyższe. Biorąc pod rozwagę choćby przewidziane nimi prawo osób z niezakończonym przewodem doktorskim przed wdrożeniem kolejnej reformy, granice czasowe obowiązywania prawnych regulacji w tych latach czyniło płynnymi.

Dla oceny rozwiązań, ograniczonej tu wyłącznie do wyższego stopnia naukowego doktora, znaczenie równoważne miały unormowania wyznaczające z jednej strony zakres nauk, w obrębie których mogły być nadawane stopnie naukowe doktora, a $z$ drugiej strony szkoły wyższe (od 1951 r. także instytuty i placówki naukowe) uprawnione do przeprowadzania przewodów doktorskich. W Polsce Ludowej nie były to rozwiązania jednolite. Uzasadnieniem dla różnych rozwiązań wtedy przyjmowanych była stopniowa odbudowa szkolnictwa wyższego już w nowych warunkach polskiej państwowości, pogłębiająca $z$ biegiem czasu, wraz z utrwalaniem wzorców radzieckich, socjalistyczny model zarządzania szkołą wyższą i ideologizująca postępowania w przewodach na stopień naukowy.

Artykuł niniejszy jest odpowiedzią na pytania: dla kogo rezerwowano prawo przeprowadzania przewodów doktorskich, jaki udział w tym procesie pozostawiono organom centralnym, a jaki organom szkół wyższych i instytutów naukowych, kto mógł ubiegać się o wszczęcie przewodu prowadzącego do nabycia wyższego stopnia naukowego doktora oraz jak ukształtowano warunki jego przebiegu, a także czy umacnianie komunistycznych założeń w Polsce powojennej w istocie oddawało powagę i znaczenie awansu naukowego ówczesnej kadry naukowej czy też nie.

W całym okresie objętym analizą (1945-1958) nie było stopnia naukowego wyższego niż stopień doktora. Jego osiągnięcie nie zamykało wszakże drogi do dalszego rozwoju kadry naukowej i jej awansu

${ }^{13}$ Na temat niższych stopni naukowych w Polsce Ludowej zob. K. Wojtczak, O stopniach naukowych w Polsce Ludowej. Część 1. Niższe stopnie naukowe, „Studia Prawa Publicznego" 2016, nr 1(13), s. 46 i n. 
naukowego. Instytucjonalnie rozwojowi temu miało sprzyjać między innymi prawo habilitowania. Postępowania habilitacyjnego pomyślnie zakończonego nie wiązano jednak z prawem nabycia stopnia naukowego. Wyjątek od prawem ukształtowanej tradycji habilitowania wprowadziła ustawa z $1951 \mathrm{r}$. Ustawa ta jako jedyna nie przewidywała postępowań habilitacyjnych, również tych (co miało miejsce w latach wcześniejszych) nieprowadzących do stopnia naukowego.

\section{Stopień naukowy doktora w pierwszych latach Polski Ludowej}

Tuż po zakończeniu II wojny światowej nadal obowiązująca ustawa o szkołach akademickich z 1933 r. zawierała bardzo skromne uregulowania odnośnie do stopni naukowych. Poza wskazaniem na nie (stopień niższy i wyższy) i zarezerwowaniem ich nadawania wyłącznie dla szkół akademickich, określenie szczegółowej ich nazwy pozostawiała ministrowi wyznań religijnych i oświecenia publicznego w drodze rozporządzenia, po wysłuchaniu opinii rad wydziałowych ${ }^{14}$. Rozporządzenie to, przy zachowaniu powyższej procedury jego powzięcia, miało zawierać m.in. przepisy o uzyskiwaniu stopni naukowych (art. 41 ust. 3). Tę delegację minister wyznań religijnych i oświecenia publicznego wypełnił dopiero w dziesiątym miesiącu od uchwalenia ustawy z $1933 \mathrm{r}$. Co więcej, rozporządzeniem z dnia 2 stycznia 1934 r. ${ }^{15}$ zarządzil, że do czasu wydania odpowiednich rozporządzeń na podstawie ustawy z dnia 15 marca 1933 r. mają być nadal stosowane obowiązujące dotychczas szczegółowe przepisy normujące uzyskiwanie akademickich stopni naukowych. Tym samym, w odniesieniu do nadawania stopnia doktora, zachował moc obowiązująca przepisów wykonawczych wydanych na podstawie wcześniejszej (z 1920 r.) ustawy o szkołach akademickich ${ }^{16}$. Dla pierwszych lat po wyzwoleniu w 1945 r. oznaczało to zachowanie w mocy nie tylko obowiązującego Rozporządzenia Ministra Wyznań Religijnych i Oświecenia Publicznego z dnia 11 listopada 1924 r. w sprawie

${ }^{14}$ Zob. też art. 41 ust. 1 Ustawy z dnia 15 III 1933 r. o szkołach akademickich - tekst pierwotny (Dz.U. RP Nr 29, poz. 406) w brzmieniu nadanym Ustawą z dnia 2 VII 1937 r. o zmianie ustawy z dnia 15 III 1933 r. o szkołach akademickich (Dz.U. Nr 52, poz. 406).

${ }^{15}$ Rozporządzenie Ministra Wyznań Religijnych i Oświecenia Publicznego z dnia 2 I 1934 r. w sprawie wykonania postanowień artykułu 41 ust. 3 ustawy z dnia 15 III 1933 r. o szkołach akademickich (Dz.U. RP Nr 29, poz. 247) - Dz.Urz. MWRiOP Nr 1, poz. 9.

${ }^{16}$ Ustawa z dnia 13 VII 1920 r. o szkołach akademickich (Dz.U. RP Nr 72, poz. 494 ze zm.). 
uzyskiwania stopnia doktora na wszystkich wydziałach państwowych szkół akademickich (Uniwersytetów, Politechnik, Akademii oraz Szkoły Głównej Gospodarstwa Wiejskiego) ${ }^{17}$, ale także rozporządzeń bądź zarządzen ${ }^{18}$, w tym zatwierdzanych przez ministra statutów szkół akademickich i wydanych na ich podstawie programów i organizacji studiów ${ }^{19}$, normujących po tej dacie szczegółowe warunki uzyskiwania stopnia doktora w zakresie nieuregulowanym rozporządzeniem z $1924 \mathrm{r}$.

Ustawa z 1933 r. nie uszczupliła liczby państwowych szkół akademickich już posiadających, na mocy ustawy z 1920 r., prawo nadawania stopni naukowych ${ }^{20}$. Przeciwnie, listę tę rozszerzyła o kolejne państwowe szkoły akademickie ${ }^{21}$, a nadto prawem tym objęła niektóre ze szkół

${ }^{17}$ Dz.Urz. MWRiOP Nr 20, poz. 207. Rozporządzenie to weszło w życie z dniem 1 I $1925 \mathrm{r}$.

${ }^{18}$ Zob. np.: Zarządzenie Ministra Wyznań Religijnych i Oświecenia Publicznego z dnia 16 III 1928 r. w sprawie organizacji studiów lekarskich w uniwersytetach państwowych (Dz.Urz. MWRiOP Nr 8, poz. 132), określające m.in. warunki uzyskiwania stopnia doktora medycyny (pkt V. Doktorat); Rozporządzenie Ministra Wyznań Religijnych i Oświecenia Publicznego z dnia 2 VIII 1938 r. w sprawie uzyskiwania stopnia doktora medycyny dentystycznej w Akademii Stomatologicznej w Warszawie (Dz.Urz. MWRiOP Nr 9, poz. 264), odsyłający w $\S 6$ wprost także do rozporządzenia z dnia 11 XI 1924 r.

${ }^{19}$ Zob. np. § 28 ust. 3 Statutu Szkoły Głównej Handlowej w Warszawie, zatwierdzonego przez Ministra Wyznań Religijnych i Oświecenia Publicznego z dniem 11 II 1935 r. (Dz.Urz. MWRiOP Nr 6, poz. 63) dający posiadaczowi stopnia magistra prawo ubiegania się o stopień doktora nauk ekonomicznych, a także §§ 32-44 (VIII. Studia doktorskie) Programu i organizacji studiów ekonomiczno-handlowych w Szkole Głównej Handlowej w Warszawie, zatwierdzonego przez Ministra Wyznań Religijnych i Oświecenia Publicznego z dniem 3 IX 1934 r. (Dz.Urz. MWRiOP Nr 6, poz. 64).

${ }^{20}$ Mocą tej ustawy, z dniem jej wejścia w życie (15 IX 1920 r.) prawa szkoły akademickiej posiadały: Uniwersytet Jagielloński w Krakowie, Uniwersytet Stefana Batorego w Wilnie, Uniwersytet Jana Kazimierza we Lwowie, Uniwersytet Warszawski, Uniwersytet Poznański, Szkoła Politechniczna we Lwowie, Politechnika Warszawska, Akademia Weterynarii we Lwowie, Szkoła Główna Gospodarstwa Wiejskiego w Warszawie, Akademia Górnicza w Krakowie (od 1949 r. Akademia Górniczo-Hutnicza w Krakowie z mocy Rozporządzenia Rady Ministrów z dnia 30 V 1949 r. w sprawie przekształcenia Akademii Górniczej w Krakowie na Akademię Górniczo-Hutniczą w Krakowie - Dz.U. Nr 36, poz. 258). Od 1924 r. listę tę poszerzono o Akademię Sztuk Pięknych w Krakowie mocą Ustawy z dnia 16 VII 1924 r. o zmianie niektórych przepisów ustawy z dnia 13 VII $1920 \mathrm{r}$. o szkołach akademickich (Dz.U. RP Nr 2, poz. 10).

${ }^{21}$ Zgodnie z art. 2 ustawy z dnia 15 III 1933 r. w jej pierwotnym brzmieniu (Dz.U. RP Nr 4, poz. 86) były to: Akademia Sztuk Pięknych w Warszawie, Akademia Stomatologiczna w Warszawie - którą zamknięto jako samodzielną państwową szkołę akademicką w 1949 r. i przekształcono w Oddział Stomatologiczny Wydziału Lekarskiego Uniwersytetu Warszawskiego na mocy Rozporządzenia Rady Ministrów z dnia 30 V 1949 r. w sprawie przekształcenia Akademii Stomatologicznej w Warszawie (Dz.U. Nr 36, poz. 259). W latach późniejszych zmieniono nazwy trzech państwowych 
prywatnych, nadając im status szkoły akademickiej22. Nie każda z tych szkół nabyła jednak przed 1939 r. pełne prawa państwowe szkół akademickich. Te spośród prywatnych szkół, które status szkoły akademickiej otrzymały z niepełnym prawem państwowym, mogły nadawać jedynie niższe stopnie naukowe (nierzadko tylko niektóre) ${ }^{23}$.

szkół akademickich: Uniwersytet Warszawski zastąpiono nazwą Uniwersytet Józefa Piłsudskiego w Warszawie, nazwę Szkoła Politechniczna we Lwowie zastąpiono nazwą Politechnika Lwowska, nazwę Akademia Weterynaryjna zastąpiono nazwą Akademia Medycyny Weterynaryjnej we Lwowie (zob. też art. 2 ustawy z 15 III 1933 r. w brzmieniu nadanym tekstem jednolitym). W sierpniu 1938 r. utworzono Akademię Wychowania Fizycznego w Warszawie o statusie wojskowej szkoły akademickiej - Ustawą z dnia 23 VIII 1938 r. o Akademii Wychowania Fizycznego Józefa Piłsudskiego w Warszawie (Dz.U. Nr 65, poz. 488), w 1949 r. uchyloną Dekretem z dnia 27 VII 1949 r. o Akademii Wychowania Fizycznego (Dz.U. Nr 46, poz. 336).

${ }_{22}$ Mocą ustawy z 15 III 1933 r. w jej pierwotnym brzmieniu prywatnymi szkołami akademickimi były: Szkoła Główna Handlowa w Warszawie (od 1949 r. Szkoła Główna Planowania i Statystyki, z mocy Dekretu z dnia 16 VIII 1949 r. o przekształceniu Szkoły Głównej Handlowej w Warszawie na Szkołę Główną Planowania i Statystyki w Warszawie - Dz.U. Nr 48, poz. 368); Katolicki Uniwersytet Lubelski, Wolna Wszechnica Polska w Warszawie. Liczbę tych szkół rozszerzono w 1937 r., zastrzegając zarazem różne daty nabycia przez nie statusu szkoły akademickiej. Chodzi tu o: Akademię Handlu Zagranicznego we Lwowie (1 X 1937 r.), Akademię Handlową w Krakowie (1 IX 1938 r.), Akademię Handlową w Poznaniu (10 XI 1938 r.), Akademię Nauk Politycznych w Warszawie (1 IX 1939 r.). Zob. art. 1 Ustawy z dnia 29 III 1937 r. o zmianie ustawy z dnia 15 III 1933 r. o szkołach akademickich - Dz.U. Nr 27, poz. 192). Szerzej zob. K. Wojtczak, O stopniach naukowych i veniam legendi..., s. 34-38.

${ }^{23}$ Zob. np. Rozporządzenie Ministra Wyznań Religijnych i Oświecenia Publicznego z dnia 8 X 1935 r. o udzieleniu Wolnej Wszechnicy Polskiej w Warszawie prawa nadawania niektórych niższych stopni naukowych (Dz.Urz. MWRiOP Nr 10, poz. 177) oraz Rozporządzenie Ministra Wyznań Religijnych i Oświecenia Publicznego z dnia 25 IX 1937 r. o udzieleniu Wolnej Wszechnicy Polskiej w Warszawie prawa nadawania niektórych niższych stopni naukowych (Dz.Urz. MWRiOP Nr 13, poz. 383); Rozporządzenie Ministra Wyznań Religijnych i Oświecenia Publicznego z dnia 9 V 1933 r. o udzieleniu Katolickiemu Uniwersytetowi Lubelskiemu prawa nadawania niektórych niższych stopni naukowych (Dz.Urz. MWRiOP Nr 10, poz. 139). Pięć lat później uniwersytet ten uzyskał pełne prawa państwowych szkół akademickich (Dz.Urz. MWRiOP Nr 27, poz. 242). Pełnych praw państwowych szkół akademickich nie posiadały także: Akademia Handlu Zagranicznego we Lwowie (Rozporządzenie Ministra Wyznań Religijnych i Oświecenia Publicznego z dnia 20 I 1939 r. o udzieleniu Akademii Handlu Zagranicznego we Lwowie prawa nadawania stopnia magistra nauk ekonomiczno-handlowych, jako niższego stopnia naukowego (Dz.U. Nr 9, poz. 47); Akademia Handlowa w Poznaniu, utworzona w 1926 r. i przekształcona dekretem z dnia 26 X 1950 r. w państwową wyższą szkołę akademicka, z mocą wsteczną od dnia 1 IX 1950 r., przyjmująca nazwę Wyższej Szkoły Ekonomicznej w Poznaniu (Dz.U. Nr 49, poz. 444), a także Akademia Handlowa w Krakowie oraz Akademia Nauk Politycznych w Warszawie. 
Rok 1945 przyniósł nową rzeczywistość. Wraz z powojenną zmianą granicy wschodniej ${ }^{24} \mathrm{z}$ mapy polskich szkół akademickich zniknęły uniwersytety, politechniki i akademie z siedzibą we Lwowie i Wilnie. Pozostałe szkoły akademickie państwowe i te spośród szkół prywatnych, które posiadały pełne prawa państwowych szkół akademickich, prawo do nadawania stopni naukowych zachowały w niezmienionym zakresie. Biorąc pod uwagę odbudowę bazy materialnej szkolnictwa wyższego ${ }^{25}$, jednocześnie otwierano uczelnie nowe ${ }^{26}$, a już istniejące przekształcano w polskie państwowe szkoły akademickie ${ }^{27}$.

W roku 1947 dekret Rady Państwa uchylił ustawę z 1933 r. ${ }^{28}$ i zarazem powierzył prawo nadawania stopni naukowych (magistra i doktora) wyłącznie wyższym szkołom akademickim. Jednocześnie Radę Ministrów zobowiązał do ustalenia, w drodze rozporządzenia, na wniosek ministra oświaty, za zgodą Rady Głównej do Spraw Nauki i Szkolnictwa

${ }^{24}$ Granicę wschodnią i północną między Polską a Związkiem Socjalistycznych Republik Radzieckich wstępnie ustalono porozumieniem z dnia 27 VII 1944 r. o polsko-radzieckiej granicy państwowej (urzędowo nie ogłoszonym), ostatecznie wytyczonej na mocy umowy zawartej w Moskwie w dniu 16 VIII 1945 r. między Tymczasowym Rządem Jedności Narodowej a rządem Związku Socjalistycznych Republik Radzieckich. Szerzej zob. L. Antonowicz, Status prawnomiędzynarodowy Rzeczypospolitej Ludowej, "Annales Universitatis Mariae Curie-Skłodowska" 2000, sectio G (prawo), t. XLVII, s. 11; W. Witkowski, Historia administracji w Polsce 1764-1989, Warszawa 2007, s. 406. Umowa z dnia 16 VIII 1945 r. weszła w życie z dniem wymiany dokumentów ratyfikujących, tj. z dniem 5 II 1946 r. (Dz.U. RP 1947 r. Nr 35, poz. 167 i 168).

${ }^{25}$ Szerzej zob. J. Borkowski, Organizacja zarządzania szkoła wyższa, Wrocław 1978, s. 8 i n.; K. Wojtczak, O ustroju szkół wyższych na przestrzeni lat 1920-1990, „Studia Prawa Publicznego" 2013, nr 3, s. 58 i n.

${ }^{26}$ Dekret Polskiego Komitetu Wyzwolenia Narodowego z dnia 23 X 1944 r. o utworzeniu Uniwersytetu Marii Curie-Skłodowskiej w Lublinie (Dz.U. Nr 9, poz. 42); Dekret z dnia 24 V 1945 r. o utworzeniu Politechniki Śląskiej (Dz.U. Nr 21, poz. 118); Dekret z dnia 24 V 1945 r. o utworzeniu Uniwersytetu Łódzkiego (Dz.U. Nr 21, poz. 119); Dekret z dnia 24 V 1945 r. o utworzeniu Politechniki Łódzkiej (Dz.U. Nr 21, poz. 120); Dekret z dnia 24 VIII 1945 r. o utworzeniu Uniwersytetu Mikołaja Kopernika w Toruniu (Dz.U. Nr 34, poz. 208); Dekret z dnia 8 X 1945 r. o utworzeniu Akademii Lekarskiej w Gdańsku (Dz.U. Nr 44, poz. 253).

${ }^{27}$ Dekret z dnia 24 V 1945 r. o przekształceniu Politechniki Gdańskiej w polską państwową szkołę akademicką (Dz.U. Nr 21, poz. 121); Dekret z dnia 24 VIII 1945 r. o przekształceniu Uniwersytetu Wrocławskiego i Politechniki Wrocławskiej na polskie państwowe szkoły akademickie (Dz.U. Nr 34, poz. 207); Dekret z dnia 15 XI 1946 r. o przekształceniu Akademii Nauk Politycznych w Warszawie na polską państwową szkołę akademicką (Dz.U. Nr 70, poz. 378).

${ }^{28}$ Uchylił także artykuły 51-53 (VII. Szkoły wyższe) ustawy z 1932 r. o ustroju szkolnictwa oraz ustawę z 1937 r. o prywatnych szkołach wyższych (art. 119 ust. 2 dekretu z 1947 r.). 
Wyższego ${ }^{29}$ (po raz pierwszy wprowadzonej do struktury organizacyjnej szkolnictwa wyższego ${ }^{30}$ ), które z ówcześnie działających państwowych szkół akademickich zachowują osobowość prawną, a także wskazał na warunki tworzenia szkół wyższych ${ }^{31} \mathrm{i}$ ich przekształcania w państwowe szkoły akademickie ${ }^{32}$.

${ }^{29} \mathrm{~W}$ dalszych rozważaniach nazywana "Radą Główną".

${ }^{30} \mathrm{~W}$ okresie obowiązywania ustaw o szkołach akademickich z 1920 i 1933 r. namiastkę Rady Głównej stanowiły zjazdy delegatów szkół wyższych (1920) oraz zjazdy rektorów szkół wyższych (1933).

${ }^{31}$ Zgodnie z art. 19 ust. 1 i 3 dekretu z 1947 r. założenie szkoły wyższej (tylko w ramach planu sieci tych szkół) oraz nadanie jej charakteru szkoły akademickiej (również przekształcenia w szkołę akademicką) wymagało rozporządzenia Rady Ministrów, na wniosek ministra oświaty, za zgodą Rady Głównej. Z tego okresu zob. Rozporządzenie Rady Ministrów z dnia 20 III 1948 r. o założeniu Akademii Lekarskiej w Szczecinie (Dz.U. Nr 21, poz. 145), od 1949 r. Pomorskiej Akademii Lekarskiej imienia generała Karola Świerczewskiego (Rozporządzenie Rady Ministrów z dnia 24 X 1949 r. w sprawie nadania Akademii Lekarskiej w Szczecinie nazwy "Pomorska Akademia Lekarska imienia generała Karola Świerczewskiego" - Dz.U. Nr 58, poz. 451); Rozporządzenie Rady Ministrów z dnia 20 III 1948 r. o założeniu Akademii Lekarskiej w Bytomiu (Dz.U. Nr 21, poz. 146), od 1949 r. istniejącej pod nazwą Śląska Akademia Lekarska imienia Ludwika Waryńskiego (Rozporządzenie Rady Ministrów z dnia 24 X 1949 r. w sprawie nadania Akademii Lekarskiej w Bytomiu nazwy „Śląska Akademia Lekarska imienia Ludwika Waryńskiego" - Dz.U. Nr 58, poz. 452); Rozporządzenie Rady Ministrów z dnia 24 X 1949 r. w sprawie założenia Akademii Lekarskich w Warszawie, Krakowie, Poznaniu, Lublinie, Łodzi i Wrocławiu (Dz.U. Nr 58, poz. 450); Rozporządzenie Rady Ministrów z dnia 3 II 1950 r. w sprawie założenia Akademii Lekarskiej w Białymstoku (Dz.U. Nr 6, poz. 57). Warto dodać, że od marca 1950 r. w nazwach wyższych szkół akademickich podległych ministrowi zdrowia wyrazy "Akademia Lekarska” zastąpiono wyrazami "Akademia Medyczna" (Rozporządzenie Rady Ministrów z dnia 3 III 1950 r. w sprawie zmiany nazwy wyższych szkół akademickich, podległych Ministrowi Zdrowia - Dz.U. Nr 9, poz. 92); Rozporządzenie Rady Ministrów z dnia 11 VIII 1950 r. w sprawie utworzenia Akademii Sztuk Plastycznych w Warszawie (Dz.U. Nr 39, poz. 354), powstałej z przekształcenia Akademii Sztuk Pięknych w Warszawie oraz Państwowej Wyższej Szkoły Sztuk Plastycznych w Warszawie w jedną wyższą akademicką szkołę artystyczna, a także Rozporządzenie Rady Ministrów z dnia 11 VIII 1950 r. w sprawie utworzenia Akademii Sztuk Plastycznych w Krakowie (Dz.U. Nr 39, poz. 355), powstałej z przekształcenia Akademii Sztuk Pięknych w Krakowie oraz Państwowej Wyższej Szkoły Sztuk Plastycznych w Krakowie; Rozporządzenie Rady Ministrów z dnia 17 XI 1951 r. w sprawie utworzenia Wyższych Szkół Rolniczych w Poznaniu i we Wrocławiu oraz zmian organizacyjnych na Uniwersytetach Poznańskim i Wrocławskim (Dz.U. Nr 60, poz. 411), którym nadano status państwowej wyższej szkoły akademickiej.

${ }^{32}$ Dekret z dnia 27 VII 1949 r. o Akademii Wychowania Fizycznego w Warszawie (Dz.U. Nr 46, poz. 336), mocą którego wojskową szkołę akademicką pod nazwą "Akademia Wychowania Fizycznego Józefa Piłsudskiego w Warszawie" przekształcono w szkołę akademicką pod nazwą "Akademia Wychowania Fizycznego imienia gen. broni Karola Świerczewskiego w Warszawie"; Rozporządzenie Rady Ministrów z dnia 5 VII 1950 r. 
Dekret nie normował zasad i trybu nadawania stopnia naukowego doktora. Zapowiadał jedynie ich ustalenie $\mathrm{w}$ drodze rozporządzenia przez ministra oświaty, za zgodą Rady Głównej. Minister oświaty w rzeczywistości rozporządzenia tego nie wydał, w kwietniu 1949 r. wydał natomiast zarządzenie ${ }^{33}$, którym wprowadził jedną zmianę $\mathrm{w}$ obowiązującym nadal rozporządzeniu ministra wyznań religijnych i oświecenia publicznego z 1924 r. w sprawie uzyskania stopnia doktora na wszystkich wydziałach państwowych szkół akademickich, dotyczącą składu komisji egzaminacyjnej. Rozporządzenie z 1924 r. uchylono dopiero w 1952 r. rozporządzeniem Rady Ministrów w sprawie warunków i trybu nadawania stopni naukowych ${ }^{34} \mathrm{w}$ zakresie nim unormowanym.

W ten sposób w przeciągu blisko trzydziestu lat (1924-1952) zasady i tryb nadawania wyższego stopnia naukowego doktora wyznaczało rozporządzenie z dnia 11 listopada 1924 r., trzykrotnie nowelizowane, przy bardzo wąskiej regulacji w tym zakresie ustawą z 1933 r. i dekretem z $1947 \mathrm{r}$.

Zgodnie z tytułem rozporządzenia z 1924 r., nieco zmienionym rozporządzeniem z 1937 r., proces doktoryzowania zastrzeżono dla wydziałów państwowych szkół akademickich. Kompetencje z tytułu sprawowanego nad nimi nadzoru ministra wyznań religijnych i oświecenia publicznego (od 1945 r. ministra oświaty) nie były szerokie. W istocie

w sprawie przekształcenia Studiów Wychowania Fizycznego przy Akademiach Medycznych w Poznaniu, Wrocławiu i Krakowie w Wyższe Szkoły Wychowania Fizycznego (Dz.U. Nr 29, poz. 273) - mocą tego rozporządzenia szkoły te stały się szkołami akademickimi; Rozporządzenie Rady Ministrów z dnia 6 IX 1950 r. w sprawie przekształcenia Akademii Nauk Politycznych w Warszawie na Szkołę Główną Służby Zagranicznej (Dz.U. Nr 42, poz. 379) przy zachowaniu statusu państwowej szkoły akademickiej; Dekret z dnia 26 X 1950 r. w sprawie przekształcenia Akademii Handlowej w Krakowie na Wyższą Szkołę Ekonomiczną w Krakowie (Dz.U. Nr 49, poz. 443) jako państwową szkołę akademicką posiadającą osobowość prawną oraz Dekret z dnia 26 X 1950 r. w sprawie przekształcenia Akademii Handlowej w Poznaniu na Wyższą Szkołę Ekonomiczną w Poznaniu (Dz.U. Nr 49, poz. 444) jako państwową szkołę akademicką wyposażoną w osobowość prawną; Rozporządzenie Rady Ministrów z dnia 13 X 1951 r. w sprawie włączenia Szkoły Inżynierskiej im. Wawelberga i Rotwanda w Warszawie do Politechniki Warszawskiej (Dz.U. Nr 54, poz. 378), przekształcając ją (Szkołę Inżynierską) zarazem w państwową wyższą szkołę akademicką.

${ }^{33}$ Zarządzenie Ministra Oświaty z dnia 23 IV 1949 r. w sprawie uzyskania stopnia doktora na wszystkich wydziałach szkół akademickich (Dz.Urz. Ministerstwa Oświaty $\mathrm{Nr} 7$, poz. 114). Zarządzenie to weszło w życie z dniem ogłoszenia z mocą obowiązującą od dnia 1 IX $1948 \mathrm{r}$.

${ }^{34}$ Rozporządzenie Rady Ministrów z dnia 26 IV 1952 r. w sprawie warunków i trybu nadawania stopni naukowych (Dz.U. Nr 24, poz. 164). 
sprowadzały się do określania zasad i warunków nadawania stopnia naukowego doktora, a także ustalania wysokości opłat egzaminacyjnych oraz promocji doktorskich. Ciężar aktu doktoryzacji spoczywał zatem na organach szkół akademickich, w nielicznych jedynie sprawach wymagających uprzedniego zezwolenia ministra. Udział i skład organów szkół akademickich w akcie doktoryzacji nie był jednak wartością stałą. Zmianom podlegały przepisy określające udział rektora i senatu w procesie doktoryzowania oraz składy rad wydziałowych i komisji egzaminacyjnych.

Procedurę doktoryzacji rozpoczynało przyjęcie przez właściwego dziekana $^{35}$ (do 1937 r. rektora ${ }^{36}$ ) wniosku ${ }^{37}$ kandydata ubiegającego się o nadanie stopnia naukowego doktora. Rektorowi pozostawiono jedynie prawo dokonywania wraz z dziekanem wydziału i głównym referentem (promotorem) promocji kandydata na stopień doktora. Senat szkoły akademickiej od roku 1937 pozbawiono prawa zatwierdzania uchwały rady wydziałowej w sprawie przyznania stopnia naukowego doktora. Ciężar przeprowadzenia aktu doktoryzacji spoczywał więc na radzie wydziałowej ${ }^{38}$ i komisji egzaminacyjnej oraz każdorazowo mianowanej przez radę komisji egzaminu ścisłego. Do rady wydziałowej należała ostateczna decyzja o odrzuceniu lub przyjęciu rozprawy doktorskiej kandydata, o jego dopuszczeniu bądź odmowie dopuszczenia do egzaminu ścisłego wraz z wyznaczaniem terminu

\footnotetext{
${ }^{35} \mathrm{~W}$ brzmieniu nadanym $\S 1$ pkt 5 rozporządzenia ministra wyznań religijnych i oświecenia publicznego z dnia 20 IV $1937 \mathrm{r}$.

${ }^{36} \mathrm{~W}$ pierwotnym brzmieniu rozporządzenia z dnia 11 XI $1924 \mathrm{r}$. kompetencję tę powierzono rektorowi, powierzając mu zarazem prawo i obowiązek wyznaczenia właściwego wydziału szkoły akademickiej, którą kierował i reprezentował na zewnątrz.

${ }^{37}$ W myśl rozporządzenia z dnia 11 XI $1924 \mathrm{r}$. kandydat był obowiązany dołączyć do wniosku: (1) metrykę chrztu lub urodzenia, (2) krótki życiorys, (3) dyplom stwierdzający uzyskanie niższego stopnia naukowego, (4) pracę naukową przepisaną na maszynie w trzech egzemplarzach, z dołączeniem do niej zaświadczenia profesora, w którego zakładzie (laboratorium, seminarium) dana praca została wykonana, (5) oświadczenia kandydata, że przedłożoną pracę naukową wykonał samodzielnie, (6) dowód uiszczenia w kwesturze pierwszej połowy opłaty egzaminacyjnej (art. 4).

${ }^{38}$ Na mocy ustawy z 15 III 1933 r., w brzmieniu nadanym Dekretem z dnia 16 XI 1945 r. o zmianie przepisów dotyczących szkół akademickich i stosunku służbowego profesorów i pomocniczych sił naukowych tych szkół (Dz.U. Nr 56, poz. 313) skład rady wydziałowej stanowili: profesorowie zwyczajni, nadzwyczajni, profesorowie tytularni, zastępcy profesorów i delegaci docentów. Mocą dekretu z października 1947 r. nieco zmieniono i rozszerzono skład rady wydziałowej. Tworzyli ją wtedy: profesorowie zwyczajni, nadzwyczajni, honorowi, tytularni, kontraktowi, zastępcy profesorów, docenci etatowi, delegaci docentów oraz delegaci adiunktów i asystentów (art. 41).
} 
egzaminu, o potwierdzeniu złożenia przez kandydata egzaminu ścisłego z podaniem jego wyniku (dostatecznie, dobrze, z odznaczeniem), a także podjęcie uchwały o przyznaniu kandydatowi stopnia doktora odpowiednich nauk, z równoczesnym zawiadomieniem o tym rektora i senatu. Dziekan lub zastępujący go prodziekan przewodniczył komisji egzaminu ścisłego. Jej skład poza przewodniczącym tworzyli: od 1924 r. - główny referent (promotor), koreferent oraz sekretarz, od 1937 r. - miejsce sekretarza zastąpiono egzaminatorem dodatkowego przedmiotu. Członkami komisji egzaminacyjnej mogli być tylko profesorowie zwyczajni oraz nadzwyczajni danego wydziału. Jedynie w sytuacjach wyjątkowych rada wydziałowa mogła powołać do tych czynności również profesorów honorowych bądź też profesorów innych wydziałów (od 1924 r.). Skład ten nieco zmieniono dopiero zarządzeniem ministra oświaty z kwietnia 1949 r. Zgodnie z nim członkami komisji egzaminacyjnej mogli być profesorowie zwyczajni, nadzwyczajni i docenci danego wydziału, a wyjątkowo w jej skład rada wydziałowa mogła także powołać profesorów honorowych, profesorów i docentów z innych wydziałów i szkół, jak również zastępców profesorów danego wydziału.

W pierwszych latach Polski Ludowej nabycie wyższego stopnia naukowego doktora było możliwe w zakresie każdej nauki czystej i stosowane $^{39} \mathrm{i}$ uwarunkowane uprzednim uzyskaniem $\mathrm{w}$ jednej z polskich szkół akademickich niższego stopnia naukowego, względnie posiadaniem dyplomu stwierdzającego otrzymanie równorzędnego stopnia naukowego w zagranicznych szkołach wyższych, nostryfikowanego przez jedną z państwowych szkół akademickich (od 1937 r.); przedstawieniem samodzielnej pracy naukowej, przyjętej przez właściwą komisję, oraz złożeniem z pomyślnym wynikiem egzaminu z przedmiotu głównego i jednego przedmiotu pobocznego. Od 1937 r. od kandydata do wyższego stopnia naukowego (doktora) bezwzględnie zatem wymagano:

1. przedstawienia dyplomu stwierdzającego ukończenie jednej z powyższych szkół akademickich z niższym stopniem naukowym;

2. przedłożenia samodzielnej pracy naukowej w języku polskim, łacińskim bądź języku wykładowym. Przedłożenie pracy doktorskiej w innym języku było dopuszczalne wyjątkowo na wniosek rady wydziałowej za zezwoleniem ministra oświaty (od maja 1950 r. ministra szkół

\footnotetext{
${ }^{39} \mathrm{~W}$ brzmieniu nadanym rozporządzeniem z dnia 20 IV $1937 \mathrm{r}$. w sprawie uzyskania stopnia doktora na wszystkich wydziałach państwowych szkół akademickich.
} 
wyższych i nauki ${ }^{40}$ ), z zastrzeżeniem dołączenia do pracy doktorskiej jej streszczenia w języku polskim. Zamiast pracy doktorskiej mogły być uwzględnione również obszerniejsze dzieła naukowe, ogłoszone drukiem przynajmniej na rok przed terminem zgłoszenia kandydata. Nadto jako praca doktorska $z$ dziedziny nauk technicznych mógł być przyjęty projekt lub konstrukcja samodzielna $\mathrm{z}$ opisem i rysunkami, wykonane w celu ubiegania się o stopień doktorski (od 1937 r.). W każdym przypadku praca doktorska miała dotyczyć zagadnień wchodzących w zakres przedmiotu głównego pierwszego stopnia naukowego i świadczyć o uzdolnieniach kandydata do samodzielnego rozwiązywania zagadnień z dziedziny nauk czystych lub stosowanych i zarazem stanowić istotne wzbogacenie tych nauk. W żadnym razie praca dyplomowa lub magisterska kandydata nie mogła być przez jej rozszerzenie lub uzupełnienie uznana za pracę doktorską.

Praca doktorska mogła być przyjęta bądź odrzucona przez radę wydziałowa, po przedłożeniu przez komisję egzaminacyjną protokołu (do 1937 r. referatu) najpóźniej po upływie trzech miesięcy od daty przedstawienia komisji rozprawy. Sytuacja pierwsza przed kandydatem otwierała dalszą drogę w przewodzie doktorskim. Tylko bowiem w tej sytuacji kandydat mógł przystąpić do dwóch egzaminów: ścisłego (rygorozumu) i dodatkowego (do 1937 r. pobocznego), związanego z przedmiotem głównym. Sytuacja druga tę drogę zamykała. Co więcej, odrzucona rozprawa doktorska kandydata przez komisję egzaminacyjna jednej szkoły nie mogła być powtórnie rozpatrywana przez komisje egzaminacyjne innych szkół akademickich;

3. złożenia dwóch egzaminów: ścisłego z przedmiotu głównego ${ }^{41}$, w obrębie którego przygotowano pracę doktorska, oraz dodatkowego. Egzamin ścisły miał formę ustną. Odnośnie do egzaminu drugiego wymagania szczegółowe określały regulaminy egzaminacyjne wydziałów poszczególnych szkół akademickich. Egzamin ścisły przeprowadzała komisja egzaminacyjna (mianowana przez radę wydziału) złożona co najmniej z czterech osób: dziekana lub zastępującego go prodziekana oraz członków rady wydziałowej każdorazowo desygnowanej przez radę wydziałową. $W$ razie równości głosów rozstrzygał głos przewodniczącego komisji egzaminacyjnej.

${ }^{40}$ Ustawa z dnia 26 IV 1950 r. o utworzeniu urzędu Ministra Szkół Wyższych i Nauki (Dz.U. Nr 21, poz. 181).

${ }^{41}$ Przystąienie do egzaminu ścisłego uzależniono od wcześniejszej wpłaty przez kandydata drugiej połowy opłaty egzaminacyjnej. 
Egzamin ścisły (indywidualnie dla każdego kandydata przeprowadzany ${ }^{42}$ ) miał służyć sprawdzeniu, czy ma on w należytej mierze przygotowanie teoretyczne potrzebne do samodzielnego wykonania przedłożonej przez niego pracy doktorskiej oraz czy jest należycie obeznany z literaturą opracowanego przezeń zagadnienia. Tylko pomyślnie złożony rygorozum potwierdzony pisemnie protokołem komisji egzaminacyjnej i przyjęty przez radę wydziałową zarazem pozwalał jej zdecydować o przyznaniu kandydatowi stopnia doktora odpowiednich nauk. Egzamin ścisły niepomyślnie złożony ${ }^{43}$ tej drogi wszakże nie niweczył. Kandydatowi pozostawiono bowiem prawo do jego powtórzenia, jeden raz, nie wcześniej jednak niż po upływie jednego roku.

Akt doktoryzacji kończyła promocja kandydata na stopień doktora i przyjęcie od niego przyrzeczenia, wręczenie kandydatowi dyplomu doktora, wystawionego w imieniu rektora i senatu szkoły akademickiej ${ }^{44}$ przeprowadzającej przewód doktorski.

Począwszy od 1925 r., oparcie aktu doktoryzacji na listopadowym rozporządzeniu ministra wyznań religijnych i oświecenia publicznego z 1924 r. bez wątpienia ujednoliciło wcześniejsze, dość rozproszone, prawo w tym zakresie. W pierwszych latach niepodległości było ono $\mathrm{z}$ jednej strony uwarunkowane stopniowym wdrażaniem dostosowywanych do polskich warunków rozwiązań obowiązujących w byłych państwach rozbiorowych. $Z$ drugiej zaś strony nacechowane było zindywidualizowanymi potrzebami państwowych szkół akademickich (wyrosłymi na gruncie obcego prawa i praktyki) i oczekiwaniami ich organów, w granicach pozostawionej szkołom autonomii.

Ale waga tego rozporządzenia była także inna. Jego obowiązywanie pod rządami dwóch ustaw o szkołach akademickich (z 1920 i 1933 r.) oraz dekretu Rady Państwa - z niewielkimi zmianami, niewątpliwie dowodziło stabilności ówczesnego prawa w zakresie uzyskiwania stopnia doktora. Dla osób z niezakończonym przewodem doktorskim miało to duży walor. Kolejne zmiany aktów rangi ustawowej w istocie pozostawały bez większego wpływu na dalszy bieg aktu doktoryzacji rozpoczętego przed kolejną reformą. Nie bez powodu ani ustawa z 1933 r., ani dekret z 1947 r.

${ }^{42}$ Wyraźnie zastrzeżono czas trwania egzaminu ścisłego - nie krócej niż jedna godzina, nie dłużej niż trzy godziny (art. 8 ust. 2 rozporządzenia z 11 XI 1924 r.).

${ }^{43}$ Złożenie egzaminu ścisłego $z$ oceną niedostateczną (także niedopuszczenie do tego egzaminu) wymagało powiadomienia rektorów wszystkich polskich szkół akademickich oraz ministra wyznań religijnych i oświecenia publicznego.

${ }^{44}$ Szerzej zob. K. Wojtczak, O stopniach naukowych..., s. 60. 
kwestii tej nie normowały w przepisach przejściowych. Istotnego znaczenia sprawa ta nabrała dopiero po zapowiedzi i wprowadzeniu z końcem 1951 r. kolejnej reformy szkolnictwa wyższego, a wraz z nią zmian dalece odmiennych od dotychczasowych w zakresie stopni naukowych.

\section{Stopień naukowy doktora w Polskiej Rzeczypospolitej Ludowej}

Ustawę z dnia 15 grudnia 1951 r. o szkolnictwie wyższym i o pracownikach nauki sejm przyjął na pół roku przed uchwaleniem w lipcu 1952 r. nowej konstytucji ${ }^{45}$ i nadaniem Polsce oficjalnej nazwy Polska Rzeczpospolita Ludowa. I choć konstytucja ta nie wprowadzała do Polski ustroju socjalistycznego, ten już wtedy był dostatecznie utrwalony i prawnie umocowany, podniesienie przyjętych nią założeń ustrojowych do rangi konstytucyjnej miało duże znaczenie w stabilizowaniu Polski jako państwa o zdeklarowanym ustroju socjalistycznym. Nie bez racji więc ustawa z 1951 r. niejako wyprzedzała ustrojowe założenia konstytucyjne w odniesieniu do sektora szkół wyższych. Przyjęte nią rozwiązania w znacznym bowiem stopniu emanowały socjalistycznymi wzorcami zarówno w odniesieniu do ustroju i zarządzania szkołami wyższymi, ideologizacji programów kształcenia, jak i badań naukowych (nacechowanych metodologią marksistowską) oraz rosnącym przekonaniem o włączeniu procesów dydaktycznych i badawczych szkolnictwa wyższego w system gospodarki planowej ${ }^{46}$. Nie mniej wyraźne odniesienie polskich rozwiązań do wzorców radzieckich dotyczyło stopni naukowych - kandydata nauk i doktora nauk.

Ustawa z 1951 r., a w ślad za nią rozporządzenie Rady Ministrów z kwietnia $1952 \mathrm{r}^{47}$, prawo nadawania stopni naukowych zastrzegły dla szkół wyższych, a także dla instytutów naukowych oraz innych placówek naukowych objętych wykazem ustalonym przez Radę Ministrów ${ }^{48}$.

${ }^{45}$ Konstytucja Polskiej Rzeczypospolitej Ludowej z dnia 22 VII 1952 r. (Dz.U. Nr 33, poz. 232).

${ }^{46}$ J. Borkowski, op. cit., s. 26.

47 § 1 ust. 1 Rozporządzenia Rady Ministrów z dnia 26 IV 1952 r. w sprawie warunków i trybu nadawania stopni naukowych.

${ }^{48}$ Wnioski o ustalenie przez Radę Ministrów wykazu szkół wyższych, instytutów naukowych oraz innych placówek naukowych składały w zakresie szkół wyższych minister szkolnictwa wyższego z inicjatywy własnej lub na wniosek innych właściwych ministrów, po zasięgnięciu opinii Prezydium Polskiej Akademii Nauk, w zakresie instytutów naukowych (placówek naukowych) - Prezydium Polskiej Akademii Nauk 
Spośród szkół wyższych prawo to służyło szkołom zarządzanym przez ministra szkolnictwa wyższego ${ }^{49}$, ale i tym, które Rada Ministrów poddała zarządowi innego ministra, a także szkołom wyższym unormowanym przepisami szczególnymi (akademie wojskowe ${ }^{50}$, wyższe szkoły artystyczne ${ }^{51}$ ). Jeśli chodzi o instytuty naukowe i inne placówki naukowe, prawo nadawania stopni naukowych powierzono Polskiej Akademii Nauk i jej placówkom naukowo-badawczym ${ }^{52}$ oraz innym instytutom naukowym ${ }^{53}$. O tym, które ze szkół wyższych i instytutów naukowych nabyły prawo nadawania stopni naukowych, przesądzały wykazy ustalone przez Radę Ministrów odrębnie dla stopnia naukowego niższego (kandydata nauk) i wyższego (doktora nauk). O ile dla niższego stopnia naukowego wykazy uprawniające szkoły wyższe i instytuty naukowe do ich nadawania powstały dość wcześnie, bo w 1952 r. dla szkół wyższych i w 1953 r. dla instytutów naukowych - później rozszerzane ${ }^{54}$, to wykazy szkół wyższych (dla poszczególnych wydziałów) i instytutów naukowych uprawnionych do nadawania stopnia doktora nauk opublikowano dopiero we wrześniu 1954 r. dla instytutów naukowych ${ }^{55}$ i w kwietniu 1955 r. w odniesieniu do szkół wyższych ${ }^{56}$. Pierwszą grupą objęto: instytuty PAN (Badań Literackich, Historii, Biologii Doświadczalnej

z inicjatywy własnej lub na wniosek właściwych ministrów, po zasięgnięciu opinii ministra szkolnictwa wyższego.

${ }^{49}$ Od 31 XII 1951 r. na mocy Ustawy z dnia 15 XII 1951 r. o przekształceniu urzędu Ministra Szkół Wyższych i Nauki w urząd Ministra Szkolnictwa Wyższego (Dz.U. Nr 67, poz. 465).

${ }^{50}$ Dekret z dnia 10 XII 1952 r. o akademiach wojskowych (Dz.U. Nr 49, poz. 324).

${ }^{51}$ Dekret z dnia 16 IX 1953 r. o szkolnictwie artystycznym (Dz.U. Nr 43, poz. 212) oraz Rozporządzenie Rady Ministrów z dnia 18 IX 1954 r. w sprawie warunków przyznawania tytułu samodzielnego pracownika nauki w wyższych szkołach artystycznych (Dz.U. Nr 45, poz. 211).

52 Ustawa z dnia 30 X 1951 r. o Polskiej Akademii Nauk (Dz.U. Nr 57, poz. 391 ze zm.); zob. także Uchwałę nr 548 Rady Ministrów z dnia 9 VII 1952 r. w sprawie przekazania Polskiej Akademii Nauk niektórych placówek naukowych (M.P. Nr A-63, poz. 953).

${ }^{53}$ Status prawny instytutów naukowych określała Ustawa z dnia 8 I 1951 r. o tworzeniu instytutów naukowo-badawczych dla potrzeb gospodarki narodowej (Dz.U. Nr 5, poz. 38). Instytuty naukowe nadawały stopień naukowy doktora nauk przy ścisłym zachowaniu warunków i trybu określonego w ustawie z 1951 r. o szkolnictwie wyższym i o pracownikach nauki oraz w rozporządzeniu Rady Ministrów z dnia 26 IV 1952 r. w sprawie warunków i trybu nadawania stopni naukowych.

${ }^{54}$ Szerzej zob. K. Wojtczak, O stopniach naukowych w Polsce Ludowej. Czesść 1..., s. 30 i n.

${ }^{55}$ Uchwała nr 624 Rady Ministrów z dnia 18 IX 1954 r. w sprawie ustalenia wykazu instytutów naukowych uprawnionych do nadawania stopnia doktora nauk (M.P. Nr 92, poz. 1020 ze zm.).

${ }^{56}$ Uchwała nr 319 Rady Ministrów z dnia 29 IV 1955 r. w sprawie ustalenia wykazu szkół wyższych uprawnionych do nadawania stopnia doktora nauk (M.P. Nr 41, poz. 400). 
im. M. Nenckiego, Matematyczny, Fizyki, Geofizyki, Geografii Polskiej, Budownictwa Wodnego, a także od stycznia 1955 r. ${ }^{57}$ - Podstawowych Problemów Techniki Polskiej i od czerwca 1957 r. ${ }^{58}$ - Badań Jądrowych, Maszyn Przepływowych, Filozofii i Socjologii, Nauk Prawnych, Chemii Fizycznej), oraz instytuty naukowe poza strukturą PAN (Państwowy Zakład Higieny, Instytut Geologiczny). W odniesieniu do drugiej grupy (szkoły wyższe) wykazem uprawniającym do nadawania stopnia doktora nauk objęto dwadzieścia osiem szkół wyższych ${ }^{59}$, w tym uniwersytety (Jagielloński w Krakowie, Łódzki, Marii Curie-Skłodowskiej w Lublinie, Mikołaja Kopernika w Toruniu, Poznański, Wrocławski im. Bolesława Bieruta, Warszawski), politechniki (Gdańską, Krakowska, Łódzka, Śląska, Warszawską, Wrocławską), akademie medyczne (w Gdańsku, Krakowie, Lublinie, Łodzi, Poznaniu, Warszawie, Wrocławiu), wyższe szkoły rolnicze (w Krakowie, Olsztynie, Poznaniu i we Wrocławiu), a także Akademię Górniczo-Hutniczą w Krakowie, Szkołę Główną Gospodarstwa Wiejskiego w Warszawie, Szkołę Główną Planowania i Statystyki w Warszawie oraz Instytut Nauk Społecznych przy Komitecie Centralnym Polskiej Zjednoczonej Partii Robotniczej.

Spośród pierwotnie przewidzianych rozporządzeniem $\mathrm{z}$ dnia 26 kwietnia 1952 r. dwudziestu nauk, w zakresie których mogły być nadawane stopnie naukowe (w tym stopień doktora nauk), w marcu 1954 r. rozszerzonych do dwudziestu jeden nauk, a w marcu 1958 r. do dwudziestu trzech, uprawnienie szkół wyższych w zakresie nadawania stopnia doktora nauk w 1955 r. sprowadzało się do dwudziestu jeden nauk ${ }^{60}$, a instytutów naukowych - do dziewięciu nauk w 1954 r. $^{61}$

${ }^{57}$ Uchwała nr 28 Rady Ministrów z dnia 15 I 1955 r. w sprawie uzupełnienia wykazu instytutów naukowych uprawnionych do nadawania stopnia doktora nauk (M.P. Nr 7, poz. 71).

${ }^{58}$ Uchwała nr 220 Rady Ministrów z dnia 27 VI 1957 r. w sprawie uzupełnienia wykazu instytutów naukowych uprawnionych do nadawania stopnia doktora nauk (M.P. Nr 54, poz. 337).

${ }^{59} \mathrm{~W}$ porównaniu do czasu z końca Polski międzywojennej, kiedy istniało dwadzieścia jeden szkół akademickich, w tym czternaście państwowych i siedem prywatnych, liczba szkół wyższych po 1945 r. uprawnionych do nadawania stopni naukowych podwoiła się.

${ }^{60}$ Od 1955 r. szkoły wyższe mogły nadawać stopień doktora nauk z zakresu nauk: astronomicznych, biologicznych, chemicznych, ekonomicznych, farmaceutycznych, filologicznych, filozoficznych, fizycznych, geograficznych, geologicznych, historycznych, matematycznych, medycznych, leśnych, pedagogicznych, prawnych, psychologicznych, rolnych, nauk o sztuce, nauk technicznych oraz nauk weterynaryjnych.

${ }^{61}$ Załącznik do uchwały nr 624 Rady Ministrów z dnia 18 IX 1954 r. wymieniał następujące zakresy nauk: filologiczne, historyczne, biologiczne, medyczne, matematyczne, fizyczne, geograficzne, techniczne i geologiczne. 
i dwunastu w 1957 r. ${ }^{62}$ Obie uchwały ustalające wykazy utracily moc obowiązująca z końcem 1972 r. ${ }^{63}$

To dość późne objęcie wykazem szkół wyższych uprawnionych do nadawania stopnia doktora nauk stawia pytanie, które $z$ nich mogły wraz z wejściem w życie ustawy z 1951 r., tj. począwszy od dnia 7 lutego 1952 r., nadawać stopień naukowy doktora nauk i w zakresie jakich nauk. W kwestii pierwszej odpowiedź jest prosta - szkoły wyższe utworzone na mocy dotychczasowych przepisów, podległe ministrom: szkolnictwa wyższego, zdrowia oraz oświaty ${ }^{64}$ (na mocy dekretu z 1947 r. wykazu szkół wyższych uprawnionych do nadawania wtedy ustanowionego wyższego stopnia naukowego doktora nie ustalono) oraz szkoły wyższe utworzone w latach następnych po wejścia w życie tej ustawy. Od 1955 r. prawo to służyło wyłącznie wydziałom szkół wyższych objętym wykazem Rady Ministrów. W kwestii drugiej natomiast odpowiedź jest tylko z pozoru prosta. Ustawa z $1951 \mathrm{r}$. marginalnie jedynie normowała sprawę dotyczącą stopnia doktora nauk, zaś określenie warunków i trybu jego nadawania w drodze rozporządzenia pozostawiła Radzie Ministrów. Ta z kolei rozporządzenie to wydała w dniu 26 kwietniu 1952 r., z mocą obowiązującą od dnia 17 maja 1952 r. Dopiero więc po tej dacie można mówić o prawnie skutecznej realizacji ustawy z $1951 \mathrm{r}$. $\mathrm{w}$ zakresie tu podniesionym. Warunki i tryb nadawania stopnia naukowego doktora nauk były określone. Jasno określony był także zakres nauk (różny od nauk wskazanych przez wcześniej obowiązujące przepisy, tj. czystych i stosowanych). Do marca 1954 r. poza dwudziestoma naukami, w zakresie których mógł być nadawany stopień doktora nauk, pozostały tylko nauki astronomiczne.

Data wejścia w życie rozporządzenia z kwietnia 1952 r. miała istotne znaczenie również dla wykonania przepisów przejściowych w nim określonych oraz niektórych z nich wskazanych ustawą. To rozłożenie

${ }^{62}$ Rozszerzonym uchwałą Rady Ministrów nr 220 z 1957 r. zakresem nauk objęto: nauki filozoficzne, nauki prawne oraz nauki chemiczne.

${ }^{63}$ Uchwała nr 304 Rady Ministrów z dnia 4 XII 1972 r. w sprawie utraty mocy obowiązującej niektórych uchwał Rady Ministrów, Prezydium Rządu, Komitetu Ekonomicznego Rady Ministrów oraz Komitetu Ministrów do spraw Kultury ogłoszone w Monitorze Polskim (M.P. Nr 58, poz. 311).

${ }^{64}$ Zob. w Dziale X. Przepisy przejściowe i końcowe. Art. 68 ust. 1 ustawy z 1951 r. w brzmieniu pierwotnym. Od 1956 r. także ministrom: spraw zagranicznych, Głównemu Komitetowi Kultury Fizycznej - art. 68 ust. 1 w brzmieniu nadanym Ustawą z dnia 10 IX 1956 r. o zmianie ustawy o szkolnictwie wyższym i o pracownikach nauki (Dz.U. Nr 41, poz. 185). 
regulacji w zakresie dotyczącym stopnia naukowego doktora nauk między przepisy przejściowe objęte ustawą i wydany na jej podstawie akt wykonawczy miało różny cel i uzasadnienie. W obu wypadkach dotyczyły wyższego stopnia naukowego wprawdzie podobnie nazywanego doktor odpowiednich nauk (przed 1952 r.) i doktor nauk (po 1952 r.), nadawanego jednak na nieco odmiennych warunkach i w różnym trybie w okresie przed i po wejściu w życie ustawy z 1951 r. Dla nabycia stopnia naukowego doktora nauk już nie wystarczało ukończenie studiów wyższych. Wymagano nabycia stopnia naukowego niższego - kandydata nauk, nierzadko poprzedzonego odbyciem aspirantury naukowej ${ }^{65}$. Nie bez racji, rozstrzygnięcia wymagała sytuacja osób z nieukończonym przewodem doktorskim przed dniem wejścia w życie ustawy z $1951 \mathrm{r}$. Ustawa sytuacji tej jednak nie rozstrzygała. Przeciwnie, dla uzasadnienia przyjętego podziału pracowników nauki na samodzielnych i pomocniczych $^{66}$ zmianom nadała charakter szerszy. Przepisami przejściowymi objęła osoby z dotychczasowymi tytułami profesora (zwyczajnego i nadzwyczajnego). Przy zachowaniu ich dotychczasowych tytułów (już jako tytułów naukowych po raz pierwszy ustawą wprowadzonych), ci pierwsi z mocy prawa uzyskali stopień naukowy doktora nauk, dla drugich stworzono możliwość jego uzyskania bez uprzedniego uzyskiwania stopnia kandydata nauk ${ }^{67}$. Podobnie, bez uprzedniego nabycia stopnia kandydata nauk, stopień doktora nauk mogły uzyskać osoby ze stopniem doktora nadanym na podstawie dotychczasowych przepisów, pod warunkiem posiadania znacznego dorobku naukowego, po przedłożeniu pracy naukowej stanowiącej twórczy wkład do rozwoju danej gałęzi wiedzy i przeprowadzeniu publicznej obrony (art. 71 ust. 4 ustawy z 1951 r.). Zarazem wymagano dochowania przyjętej procedury, poczynając od wszczęcia przewodu doktorskiego, aż do zatwierdzenia

${ }^{65} \mathrm{Na}$ ten temat zob. K. Wojtczak, O stopniach naukowych w Polsce Ludowej. Część 2. Organizacja aspirantury naukowej i studiów doktoranckich, "Studia Prawa Publicznego" 2016, nr 2(14), s. 50-64.

${ }^{66}$ W myśl art. 47 ust. 2 i 3 ustawy z 1951 r. samodzielnym pracownikiem nauki był pracownik nauki, który wykazał się poważnym dorobkiem naukowym i uzyskał tytuł naukowy profesora zwyczajnego, nadzwyczajnego lub docenta. Tytuły dla tej grupy pracowników nauki przewidziane przyznawała Centralna Komisja Kwalifikacyjna. Natomiast pomocniczym pracownikiem nauki byli ci spośród pracowników nauki, którzy ukończyli studia oraz wykazali się zdolnością do samodzielnych badań naukowych i uzyskali tytuł adiunkta, starszego asystenta lub asystenta.

${ }^{67}$ Profesorowie nadzwyczajni mogli uzyskać stopień naukowy doktora nauk po przedłożeniu pracy naukowej i przeprowadzeniu nad nią publicznej rozprawy (art. 71 ust. 2 w zw. z art. 43 ust. 3 i 4 ustawy z 1951 r.). 
niezaskarżonej decyzji rady wydziałowej o nadaniu stopnia doktora nauk przez Centralną Komisję Kwalifikacyjną dla Pracowników Nauki ${ }^{68}$ ( $\S$ 21-26 rozporządzenia z 1952 r.).

O niezakończonych postępowaniach habilitacyjnych i przewodach doktorskich rozstrzygały wyłącznie przepisy przejściowe rozporządzenia z 1952 r. Sytuację pierwszą uzasadniało m.in. odstąpienie od habilitacji jako jednej z dróg awansu zawodowego. Rozwiązaniem objęto tylko te osoby, których prace habilitacyjne zostały przyjęte przez radę wydziałową przed dniem wejścia w życie ustawy z 1951 r. Osoby te mogły uzyskać stopień doktora nauk po przeprowadzeniu obrony pracy, jako pracy doktorskiej, na publicznej rozprawie. Na wniosek zainteresowanego rada wydziałowa wyznaczała termin publicznej rozprawy. Na niej też spoczywał obowiązek przesłania pracy doktorskiej Centralnej Komisji Kwalifikacyjnej, ogłoszenia w prasie o terminie publicznej rozprawy, a po jej zamknięciu - przesłania CKK decyzji o nadaniu stopnia doktora nauk.

Inaczej postąpiono w odniesieniu do przewodów doktorskich. Przepisami przejściowymi przewidziano dwa rozwiązania skierowane do osób, których prace doktorskie zostały przyjęte przez radę wydziałową przed dniem 15 grudnia $1951 \mathrm{r}$. (zatem nie przed dniem wejścia w życie ustawy $\mathrm{z}$ tej daty). Zgodnie $\mathrm{z}$ rozwiązaniem pierwszym osoby te $\mathrm{w}$ celu otrzymania stopnia doktora określonego $\mathrm{w}$ dotychczasowych przepisach mogły dopełnić warunków wymaganych rozporządzeniem z dnia 11 listopada $1924 \mathrm{r}$. w terminie dwumiesięcznym od dnia wejścia w życie rozporządzenia z kwietnia 1952 r. (§ 27 ust. 1). Rozwiązanie drugie natomiast proponowało, $\mathrm{w}$ razie zakwalifikowania pracy doktorskiej jako odpowiadającej wymaganiom pracy kandydackiej, wystąpienie osoby zainteresowanej $\mathrm{z}$ wnioskiem o przeprowadzenie przewodu kandydackiego ( $\$ 27$ ust. 2).

Rozwiązanie pierwsze skłania do oceny terminu dwumiesięcznego. Biorąc pod rozwagę termin dwóch miesięcy, liczony od dnia wejścia w życie rozporządzenia z 1952 r., tj. od dnia 17 maja 1952 r., wydaje się on dość krótki dla dopełnienia według przepisów dotychczasowych warunków w przewodzie doktorskim. Uwzględniając jednak przepisy dotychczasowe oraz objęcie paragrafem 27 ust. 1 rozporządzenia z 1952 r. jedynie prac doktorskich przyjętych przez radę wydziałową przed dniem 15 grudnia 1952 r., termin dla zamknięcia przewodu

\footnotetext{
${ }^{68} \mathrm{~W}$ dalszych rozważaniach nazywaną "Centralną Komisją Kwalifikacyjną" lub „CKK”.
} 
doktorskiego najpóźniej do 17 lipca 1952 r. wydaje się bardziej realny, a w każdym razie możliwy do zrealizowania celu, tj. złożenia dwóch egzaminów (ścisłego i z przedmiotu dodatkowego), pod warunkiem że rada wydziałowa, decydując o przyjęciu rozprawy doktorskiej, po pierwsze, wyznaczyła termin egzaminu ścisłego, a po jego pozytywnym złożeniu przez kandydata zdążyła o tym orzec przed upływem dwumiesięcznego okresu, po drugie, regulaminy egzaminacyjne wydziałów poszczególnych szkół akademickich nie stały na przeszkodzie wyznaczenia terminu egzaminu z przedmiotu dodatkowego, a kandydat egzamin ten złożył $\mathrm{z}$ wynikiem pomyślnym także przed końcem drugiego miesiąca, liczonego od dnia 17 maja 1952 r.

W rozwiązaniu drugim, będącym pewną alternatywą niewymagającą dochowania limitu dwumiesięcznego, co dość oczywiste wobec wprowadzenia rewolucyjnych zmian odnośnie do stopni naukowych, do refleksji skłania możliwość zakwalifikowania pracy doktorskiej przyjętej przez radę wydziałową przed dniem 15 grudnia 1951 r. jako pracy kandydackiej i na wniosek osoby zainteresowanej przeprowadzenia przewodu kandydackiego. Temu rozwiązaniu nie stały na przeszkodzie przepisy rozporządzenia z 1952 r. wprost wyłączające przepisem przejściowym stosowanie jego postanowień dotyczących warunków, jakie powinna spełniać praca kandydacka i jej przyjęcie. Tym samym postawiono tu znak równości między pracami doktorskimi a kandydackimi ${ }^{69}$, radzie wydziałowej dano zaś możliwość działania według własnej oceny rzeczy.

Bez wątpienia, pozostawienie wyboru drogi kariery naukowej w każdej sytuacji jest oceną trafną. W sytuacji kwalifikacji przez radę wydziałowa pracy doktorskiej jako kandydackiej dla jej autora rodziło to dalej idące konsekwencje: złożenie egzaminów kandydackich ${ }^{70}$ oraz obronę

${ }^{69}$ Nie inaczej rozstrzygnięto ten problem także w przepisach przejściowych Ustawy z dnia 5 XI 1958 r. o szkołach wyższych. Zgodnie z nimi osoby posiadające stopień naukowy niższy - kandydata nauk (nadany zgodnie z przepisami ustawy z dnia 15 XII 1951 r. i rozporządzenia z dnia 26 IV 1952 r.) oraz osoby, które uzyskały stopień naukowy wyższy - doktora określonych nauk (na podstawie przepisów obowiązujących przed dniem 15 XII 1951 r., tj. dekretu z dnia 28 X 1947 r. oraz rozporządzenia z dnia 11 XI 1924 r.), wraz z wejściem w życie ustawy z dnia 5 XI 1958 r. uzyskały z mocy prawa niższy stopień naukowy doktora przewidziany tą ustawą (art. 144 ust. 2 i 3 ustawy z 1958 r. o szkołach wyższych).

${ }^{70}$ Egzaminy kandydackie obejmowały: (1) materializm dialektyczny i historyczny, (2) dyscyplinę podstawową dla danej gałęzi nauki, (3) dyscyplinę specjalną odpowiadającą tematowi pracy kandydackiej; były składane przed komisją egzaminacyjną 
zakwalifikowanej pracy doktorskiej jako kandydackiej na publicznej rozprawie, na warunkach określonych w §§ 14-18 rozporządzenia. Oznaczało to także odłożenie na dalszy okres możliwości nabycia stopnia naukowego wyższego - doktora nauk ${ }^{71}$.

Niewątpliwie, objęte przepisami przejściowymi rozwiązania w zakresie nadawania stopni wyższych porządkowały stan prawny przez pogodzenie rozwiązań dotychczasowych z nowymi. Ich ratio legis było jednak głębsze. Rok 1951 był ucieleśnieniem szczególnych nacisków dla akceptacji sowieckich wzorców nauki budowanej na marksistowskiej metodologii, a także ukształtowania moralno-zawodowych postaw badaczy. Nie bez powodu przebudowie ideologicznej towarzyszyła weryfikacja tytułów (z wyłączeniem profesorów zwyczajnych) i stopni uzyskanych na podstawie dotychczasowych przepisów. Wprawdzie dokonanie tego zabiegu było możliwe na wniosek osoby zainteresowanej (poczynając od profesora nadzwyczajnego, a kończąc na osobie z nieukończoną habilitacją i pracą doktorską), jednak przedstawicieli ówczesnej kadry naukowej stawiało to w sytuacji trudnego wyboru - w konsekwencji szczególnie istotnego dla ich dalszej kariery akademickiej.

Na mocy ustawy o stopień doktora nauk mogli ubiegać się kandydaci nauk, którzy przedłożyli pracę naukową stanowiącą twórczy wkład do rozwoju danej gałęzi nauki (art. 43 ust. 3). Rozporządzenie z 1952 r. kwestię tę normowało nieco szerzej, radzie wydziałowej pozwalało bowiem na wszczęcie przewodu doktorskiego także na podstawie wskazania tematu pracy doktorskiej, w załączniku do podania ${ }^{72}$.

Wszczęcie przewodu doktorskiego otwierało drogę do nadania stopnia doktora nauk, w którym poza osobą zainteresowaną jego uzyskaniem uczestniczyły różne podmioty: usytuowane zarówno poza

wyznaczoną przez rektora szkoły wyższej lub radą naukową instytutu naukowego (placówki naukowej) - §§ 7-8 rozporządzenia Rady Ministrów z dnia 26 IV 1952 r.

${ }^{71}$ Przepisy przejściowe ustawy z dnia 5 XI 1958 r. o szkołach wyższych inaczej potraktowały jedynie osoby legitymujące się dwoma posiadanymi stopniami naukowymi: doktora określonych nauk (uzyskanego na podstawie obowiązujących przepisów przed dniem wejścia w życie ustawy z dnia 15 XII 1951 r.), a ponadto kandydata nauk (uzyskanego w okresie mocy obowiązującej ustawy z dnia 15 XII 1951 r.). Osoby te mogły być powoływane na stanowiska samodzielnych pracowników nauki bez uzyskania stopnia naukowego docenta. Przy ubieganiu się o stopień naukowy docenta mogła być jako rozprawa habilitacyjna przedłożona wyłącznie praca kandydacka (art. 145 Ustawy z dnia 5 XI 1958 r. o szkołach wyższych).

${ }^{72}$ Do podania o wszczęcie przewodu doktorskiego należało dołączyć: „1) życiorys, 2) temat pracy doktorskiej lub gotową pracę, 3) spis prac naukowych, 4) dowód uzyskania stopnia kandydata nauk" (§ 20 rozporządzenia z 1952 r.). 
szkołami wyższymi i instytutami naukowymi, jak i w strukturze organizacyjnej tych szkół i instytutów. Minister, któremu podlegała szkoła wyższa, rozstrzygał zażalenie od decyzji rektora odmawiającej wszczęcia przewodu doktorskiego, a w odniesieniu do placówek naukowych podległych PAN - jej prezydium. Centralna Komisja Kwalifikacyjna zatwierdzała decyzję rady wydziałowej o nadaniu stopnia doktora nauk. Rektor (kierownik instytutu naukowego lub innej placówki naukowej) podejmował decyzję o wszczęciu przewodu doktorskiego, a senat przesyłał CKK niezaskarżoną decyzję rady wydziałowej o nadaniu stopnia doktora nauk.

Ciężar przewodu doktorskiego w istocie spoczywał na radzie wydziałowej i radzie naukowej. Rada (wydziałowa, naukowa) po otrzymaniu pracy doktorskiej wyznaczała co najmniej dwóch referentów pracy spośród samodzielnych pracowników nauki, w tym jednego spoza danej szkoły wyższej (instytutu naukowego, placówki naukowej). Na niej też spoczywał obowiązek przesłania Centralnej Komisji Kwalifikacyjnej i Polskiej Akademii Nauk przyjętej pracy doktorskiej na sześć tygodni przed terminem rozprawy, z jednoczesnym podaniem miejsca i daty publicznej rozprawy, nazwisk referentów oraz miejsca, w którym można było zaznajomić się z pracą. O publicznej rozprawie rada ponadto ogłaszała w prasie miejscowej co najmniej na dziesięć dni przed rozprawą.

Wszczęcie przewodu doktorskiego inicjowało podanie kandydata, w następstwie związane z przygotowaniem rozprawy doktorskiej, jeśli jej dołączenie do podania nie było możliwe. Za pracę doktorską mogła być uznana praca stanowiąca twórczy wkład do rozwoju danej gałęzi nauki, stanowiąca samodzielną pracę badawcza, w wyniku której osiągnięte rozwiązania lub teoretyczne uogólnienie problemów naukowych miały poważne znaczenie naukowe. Praca miała być po jej przyjęciu ogłoszona drukiem. Odstąpienie przez radę wydziałowa (naukową) od jej ogłoszenia wprawdzie było możliwe, lecz za zgoda przewodniczącego CKK. Jako praca doktorska mogła być również przyjęta praca naukowa uprzednio już ogłoszona. Kandydat był obowiązany przedłożyć radzie (wydziałowej, naukowej) pięć egzemplarzy pracy doktorskiej we wskazanym przez nią terminie, co pozwalało jej na wyznaczenie co najmniej dwóch referentów. Pisemne opinie referentów o pracy, sporządzone $\mathrm{w}$ terminie ustalonym przez radę (wydziałowa, naukową), miały zawierać analizę i krytykę pracy oraz ocenę, czy praca odpowiada stawianym jej wymaganiom. Opinie niezawierające analizy, 
krytyki i oceny mogły być referentom zwracane w celu ich ponownego opracowania lub uzupełnienia.

Rada (wydziałowa, naukowa) mogła przyjąć lub odrzucić pracę doktorską zwykłą większością głosów. W sytuacji pierwszej zarazem wyznaczała termin publicznej rozprawy doktorskiej, w sytuacji drugiej natomiast powiadamiała kandydata o przyczynach jej odrzucenia. Od decyzji negatywnej kandydat mógł w terminie trzydziestu dni od dnia jej doręczenia odwołać się (za pośrednictwem rektora, kierownika instytutu naukowego, placówki naukowej) do Prezydium CKK. Prezydium mogło decyzję tę uchylić i wyznaczyć inną radę wydziałową (radę naukową) dla rozpatrzenia pracy i ewentualnego przeprowadzenia dalszego toku przewodu doktorskiego. Decyzja wyznaczonej rady (wydziałowej, naukowej) była ostateczna.

Obrona przyjętej pracy doktorskiej odbywała się na publicznej rozprawie, według przyjętego rozporządzeniem z 1952 r. porządku: (1) zapoznanie przez przewodniczącego zebranych z tematem pracy doktorskiej i w sposób zwięzły przedstawienie przebiegu dotychczasowej działalności naukowej i naukowo-dydaktycznej autora; (2) przedstawienie przez autora podstawowych tez i wniosków swej pracy; (3) przeprowadzenie przez referentów szczegółowej jej oceny, po której (4) osoby obecne na rozprawie mogły zadawać pytania, a autor był obowiązany udzielić na nie odpowiedzi; (5) przeprowadzenie dyskusji, na końcu której autor miał ustosunkować się do oceny i głosów w niej zabieranych. Rada (wydziałowa, naukowa) po naradzie (bez publiczności) w drodze tajnego głosowania (zwykłą większością głosów przy obecności co najmniej $2 / 3$ członków rady) decydowała o nadaniu lub odmowie nadania stopnia doktora nauk, po czym przewodniczący ogłaszał zebranym na rozprawie wynik głosowania i treść decyzji.

Od decyzji rady (wydziałowej, naukowej) o nadaniu lub o odmowie nadania stopnia doktora nauk służyło każdej osobie zainteresowanej odwołanie do CKK, za pośrednictwem rektora (kierownika instytutu lub innej placówki naukowej), w ciągu trzydziestu dni od jej ogłoszenia. Jednak tylko niezaskarżona decyzja rady wydziałowej o nadaniu stopnia doktora nauk mogła i miała być przesyłana do zatwierdzenia Centralnej Komisji Kwalifikacyjnej. W ten sposób odstąpiono od badania przez CKK słuszności odwołania dotyczącego odmowy nadania stopnia doktora nauk, a przyjętego dla odmowy nadania stopnia kandydata nauk. Centralna Komisja Kwalifikacyjna mogła zatwierdzić decyzję rady (wydziałowej, naukowej) lub odmówić jej zatwierdzenia 
w przedmiocie nadania stopnia doktora nauk. W sytuacji pierwszej zwracała akta kandydata właściwej radzie w celu wydania dyplomu, w sytuacji drugiej natomiast decyzję rady (wydziałowej, naukowej) uchylała. Decyzje CKK były ostateczne.

\section{Podsumowanie}

W Polsce Ludowej wyższe stopnie naukowe określały przepisy pochodzące $z$ różnych lat i o różnej randze (ustawy, dekrety, rozporządzenia, zarządzenia, statuty szkół wyższych, regulaminy). Stosownie do obranej formy działania zmieniały się organy właściwe (poza sejmem) do stanowienia aktów prawnych normujących sprawy nadawania wyższego stopnia naukowego oraz organy uczestniczące w przewodach na stopień doktora. Tej dynamice towarzyszyła rozbudowa potencjału szkolnictwa wyższego przez tworzenie nowych szkół wyższych i przekształcanie szkół wcześniej powstałych. Bazę tę od 1951 r. rozszerzono o Polską Akademię Nauk i jej placówki naukowe oraz o instytuty naukowe usytuowane poza jej strukturą. Do tego roku sprawy nadawania stopni naukowych pozostawiono wyłącznie prawu szkolnictwa wyższego.

W pierwszych latach Polski Ludowej prawo nadawania wyższego stopnia doktora cechowała względna stabilność. I choć prawo szkół wyższych zmieniało się, wymagania stawiane kandydatom do stopnia doktora, jak i przebieg aktu doktoryzacji w latach 1924-1952 poddano zmianom nieznacznym. Rewolucyjny charakter przemian przyniósł koniec roku 1951. Odtąd obowiązywały rozwiązania oderwane od polskiej tradycji, oparte na wzorcach radzieckich. Polityczne uwarunkowania zmian dyktowały potrzebę weryfikacji kwalifikacji zawodowych i moralnych kadry nauczającej (odtąd samodzielnych i niesamodzielnych pracowników nauki), oraz ukierunkowanie badań naukowych na społeczny i gospodarczy rozwój socjalistycznego państwa. W tym samym kierunku szły rozwiązania dotyczące prac badawczych na stopień naukowy, utożsamianych po raz pierwszy, za wzorem sowieckim, ze stopieniem kandydata nauk, którego uzyskanie (poza wyjątkami) legitymowało otwarcie drogi do wszczęcia przewodu doktorskiego, i z nabyciem stopnia doktora nauk.

Formułowane prawem wymagania $\mathrm{w}$ przewodach doktorskich na stopień doktora określonej nauki (do 1952 r.) i stopień doktora nauk (po wejściu w życie ustawy z 1951 r.) nie były znacząco różne. W obu 
przypadkach prace doktorskie miały dowieść umiejętności kandydata do samodzielnego rozwiązywania zagadnień objętych pracą doktorską i stanowić istotne wzbogacenie nauk czystych i stosowanych (do 1952 r.), twórczy wkład do rozwoju danej gałęzi nauki (po 1952 r.). W obu przypadkach rada wydziałowa powierzała dokonanie oceny pracy doktorskiej dwóm referentom. Od 1952 r. jednym z nich miał być samodzielny pracownik nauki spoza danej szkoły wyższej (instytutu naukowego, placówki naukowej).

Istotne różnice dotyczyły dalszych stadiów postępowania. Dla nabycia stopnia doktora rada wydziałowa orzekała na podstawie referatu komisji egzaminacyjnej o przyjęciu lub odrzuceniu pracy doktorskiej. W razie jej przyjęcia wyznaczała termin egzaminu ścisłego. Po pomyślnym złożeniu tego egzaminu oraz egzaminu z przedmiotu dodatkowego decydowała o nadaniu stopnia doktora określonych nauk. Tymczasem dla nadania stopnia doktora nauk wprawdzie rada wydziałowa (rada naukowa) także orzekała o przyjęciu lub odrzuceniu pracy doktorskiej, jednak decyzja rady o jej odrzuceniu była ostateczna. Wraz z decyzją pozytywną rada (wydziałowa, naukowa) wyznaczała termin publicznej rozprawy doktorskiej. Tylko decyzja pozytywna rady (wydziałowej, naukowej), powzięta po zamknięciu dyskusji, prowadziła do nadania stopnia doktora nauk. Decyzja w tym przedmiocie wymagała zatwierdzenia przez Centralną Komisję Kwalifikacyjną.

\section{HIGHER DOCTORAL DEGREES IN THE POLISH PEOPLE'S REPUBLIC}

\section{S u m mary}

A higher academic degree that could be earned in the Polish People's Republic was that of a doctor of a given branch of science (until 1951) or a doctor of science (1951-1958). These degrees were conferred pursuant to different legislative acts of varying importance including an act of parliament, a decree, an order, a regulation or a statute, all of them governing the regime and the functioning of schools of higher education and other establishments of tertiary education. While the legal provisions applicable to the conferral of academic degrees were relatively stable in the intitial postwar years (and were subject to the same law binding in 1924-1952 with only minor amendments), the law adopted in 1951 introduced more revolutionary changes. Based on the Soviet model, they virtually broke with the Polish tradition of higher academic degrees.

During the analysed period, alongside the reforms in the conferral of degrees, also the requirements and conditions for candidates for a higher academic degree were changing. Likewise, organs participating in the process, operating within 
the organisational structures of the establishments as well as those outside their structures, were a subject to change. Hence an attempt in this article to answer the following questions: (1) for whom was the right to register candidates for a doctor's degree reserved, (2) what was the level of participation of the central organs in the process, and what was the level of involvement of the establishments of higher education and other scientific institutions (as of 1951), (3) who could apply for registration and what were the regulations governing the whole process, and whether (4) the communist regulations governing the process of the conferral of academic degrees actually added to their importance and the academic advancement or rather acted to the contrary.

An important element in the analysis was identification of the legally formulated and applied requirements which doctoral dissertations had to meet, as well as examination of the grades or evaluations given by reviewers of doctoral dissertations in years 1945-1951 and 1952-1958.

Keywords: People's Poland - degree of a doctor of a given branch of science - Polish People's Republic - degree of a doctor of science - conditions of the conferral of higher academic degrees 